\title{
A COMPARATIVE STUDY TO ASSESS THE LEVEL OF DEPRESSION BETWEEN ELDERLY LIVING AT OLD AGE HOME AND LIVING WITH FAMILIES IN HARYANA
}

\author{
*Sonia Devi ${ }^{1}$ \\ ${ }^{* 1}$ Research scholar (Nursing), \\ Shri JJT University, \\ Jhunjhunu, \\ Rajasthan, \\ India.
}

\author{
Suman $^{2}$ \\ ${ }^{2}$ Research Scholar (Nursing), \\ Shri JJT University, \\ Jhunjhunu, \\ Rajasthan, \\ India.
}

\author{
Dr. Santosh Gurjar ${ }^{3}$ \\ ${ }^{3}$ Principal, \\ RPIITs Karnal, \\ Haryana, \\ India.
}

Article DOI: https://doi.org/10.36713/epra5119

\begin{abstract}
Background and aim: Depression has always been a health problem for human beings. Historical documents written by healers, philosophers, writers, throughout the age point to the longstanding existence of depression as a health problem, and the continuous and sometime ingenious struggle people have made to find effective ways to treat this illness. In the study the aim to assess the level of depression between elderly living at old age home and living with families in Haryana. Materials and Methods: A comparative study to assess the depression between elderly living at old age home and living with families in selected Haryana. 100samples were selected by cluster sampling technique in each stratum have 50 samples. Data was collected with the help of Hamilton depression rating scale. Data analyzed by Descriptive (Mean, Median, Mode, Standard Deviation) and inferential technique. Results: Level of depression among elderly living in old age home 2\% having normal level of depression, $34 \%$ mild depression, $46 \%$ moderate depression, $4 \%$ severe depression, $14 \%$ very severe depression and Level of depression among elderly living with family members $46 \%$ having normal depression, 44\% having mild depression, 08\% having moderate depression, $2 \%$ having severe depression. Conclusion: The study shown that assess the level of depression between elderly living at old age home and living with families in Haryana.
\end{abstract}

KEY WORDS: Comparative, Knowledge, Elderly, Depression, Old age Home

\section{INRODUCTION}

The global share of people aged $\geq 60$ years has increased from $9.2 \%$ (1990) to $11.7 \%$ (2013) and is projected to reach $21.1 \%$ of the world's population by 2050. Globally, the number of people $\geq 60$ years is expected to more than double, from 841 million people in 2013 to more than 2 billion in 2050. [1] India has around 104 million older adults $(8.6 \%$ of the country's total population) and the number is expected to increase to 296.6 million, constituting 20 per cent of the total population by 2050. [2] As the ageing population is becoming more and more pronounced, the concern for the quality of life (QOL) and well-being of the older adults is also growing both in developing and developed countries. The World Health Organization describes the QOL as a broad-ranging concept that incorporates individual's physical health, psychological state, level of independence, social relationships, personal beliefs and their association to salient features of the environment. [3] The depression in the elderly should never be considered as a natural consequence 
of ageing. It usually has an atypical presentation. It can manifest as a symptom e.g. as a reaction to stress: as a syndrome ex: secondary to hypertension or Parkinson's disease; and as an illness e.g. endogenous depression. [4] India has acquired the label of an aging nation with $8.6 \%$ of its population being more than 60 years old. [5] Depression is a common mental disorder characterized by sadness, loss of interest or pleasure, feeling of guilt or self-esteem, disturbed sleep or appetite and poor concentration. It can affect anyone, of any culture, age or background but older people are affected than any other age group. ${ }^{[6]}$ Depression in elderly lowers the productivity and increases health care financial burden to the family members. Finding out prevalence of depression among older adults living in old age home and community provides the information about the impetus we should give on mental health care. For this reason, it was imperative to study the prevalence of depression among elderly people. [7] Although the elderly suffers from medical illness there is a greater contribution to mental health problems, especially the priority goes to depression. Depression is pervasive and can diminish the spark of life. Depression is a mood disturbance characterized by exaggerated feelings to sadness, despair, lowered self-esteem, loss of interest in former activities and pessimistic thoughts. Depressive disorders are the most common affective illness found in old age. Elderly suffering from acute or chronic illness showed higher prevalence of depression. The incidence of increased depression among the elderly is influenced by the variables of physical illness, functional disability and cognitive impairment. [8] Higher suicidal rates are also associated with depression. Over the past decades India's health programmed and policies have been concentrating on issues like population stabilization, maternal and child health and disease control, However the current statistics for the elderly in India gives an overture to a new set of medical, social and economic problems that could arise if a timely initiative in this direction is not taken by the program managers and policy makers. [9]

\section{OBJECTIVE OF STUDY}

$>$ To assess the level of depression among elderly living at old age home.

$>$ To assess the level of depression among elderly living with families.

$>$ To compare the level of depression among elderly who are living at old age home and living with families.

$>$ To assess the association between level of depression among elderly living at old age home and demographic variable.

$>$ To assess the association between level of depression among elderly living with families and demographic variable.

\section{HYPOTHESIS}

H1- To find out significant difference in the level of depression among elderly living at old age home and with families.

H2- To find out significant association in the level of depression among elderly living at old age home with selected demographic variable.

H3- To find out significant association in the level of depression among elderly living variable. with families with selected demographic

\section{ASSUMPTIONS}

Elderly people living at old age home and elderly living with families will be having some knowledge regarding depression.

\section{DELIMITATIONS}

$>$ The study is delimited to only a period of 4 weeks.

$>$ The study is delimited to $60-85$ years of age group.

$>$ The study is delimited to only selected village at Jind.

$>$ The study is delimited to only 100 samples of elderly people.

\section{REVIEW OF LITERATURE}

Section -1: Reviews related to studies of depression.

Section-2: Reviews related to reducing depression among old age.

\section{METHODOLOGY}

Research approach: Quantitative approach

Research design: Non-experimental descriptive design

Variables:

Independent variables: Hamilton rating scale

Dependent variables: Knowledge of the level of depression among elderly living at old age home and elderly living with families.

Setting of the study: selected area Haryana.

Population: elderly people of old age home and elderly living with families of Haryana.

Sample: elderly people (60-85-year age group)

Sample size: Sample size consists of 100 elderly living at old age home and elderly living with families in Haryana.

Sampling Technique: cluster sampling technique. 
EPRA International Journal of Multidisciplinary Research (IJMR) - Peer Reviewed Journal

Volume: 6 | Issue: 9 | September 2020 || Journal DOI: 10.36713/epra2013 || SJIF Impact Factor: 7.032 ||ISI Value: 1.188

\section{RESULTS \& INTERPRETATION}

Table: 1- shows frequency and percentage level of Depression among elderly living at old age home in the group.

\begin{tabular}{|c|c|c|}
\hline \multirow{2}{*}{ Level of Depression } & \multicolumn{2}{|c|}{ Elderly living at old age home } \\
\cline { 2 - 3 } & Frequency(f) & 2 \\
\hline Normal (0-7) & 01 & 34 \\
\hline Mild (8-16) & 17 & 46 \\
\hline Moderate (17-23) & 23 & 4 \\
\hline Severe (24) & 02 & 14 \\
\hline Very Severe (more than 24) & 07 & Percentage (\%) \\
\hline
\end{tabular}

Shows frequency and percentage level of home 01(2\%) belongs to normal level of depression, Depression among elderly living at old age home in the group.

The above table describes the frequency and percentage level of depression among elderly living in old age followed by $17(34 \%)$ with mild level of depression $23(46 \%)$ with moderate level of depression,02(4\%) with severe level of depression and $07(14 \%)$ with very severe level of depression in the group.

Table :2- frequency and percentage distribution of two level of Depression among elderly living with family members in the group

\begin{tabular}{|c|c|c|}
\hline \multirow{2}{*}{ Level of Depression } & \multicolumn{2}{|c|}{ Elderly living with family members } \\
\cline { 2 - 3 } & Frequency(f) & Percentage (\%) \\
\hline Normal (0-7) & 23 & 46 \\
\hline Mild (8-16) & 22 & 44 \\
\hline Moderate (17-23) & 04 & 08 \\
\hline Severe (24) & 01 & 02 \\
\hline Very severe (more than 24) & 0 & 0 \\
\hline
\end{tabular}

The above table describes the frequency and percentage.

Level of depression among elderly living with family members $23(46 \%)$ belongs to normal level of depression, followed by $22(44 \%)$ with mild level of depression $04(08 \%)$ with moderate level of depression,01(2\%) with severe level of depression and

none of the elderly with very severe level of depression in the group.

Table: 3- Comparison of mean, standard deviation among elderly living in old age homes and living with family members in the groups using paired $t$ test. Reference group Mean Standard Deviation.

\begin{tabular}{|c|c|c|}
\hline \multicolumn{3}{|c|}{$\begin{array}{c}\text { Comparison standard deviation among elderly living in old age homes and living with family } \\
\text { members. }\end{array}$} \\
\hline Reference group & Mean Standard & Deviation \\
\hline Living at old age home & 18.16 & 5.569 \\
\hline Living with family & 14.533 & 3.922 \\
\hline
\end{tabular}

The above table describes the knowledge scores regarding elderly living in old age home 


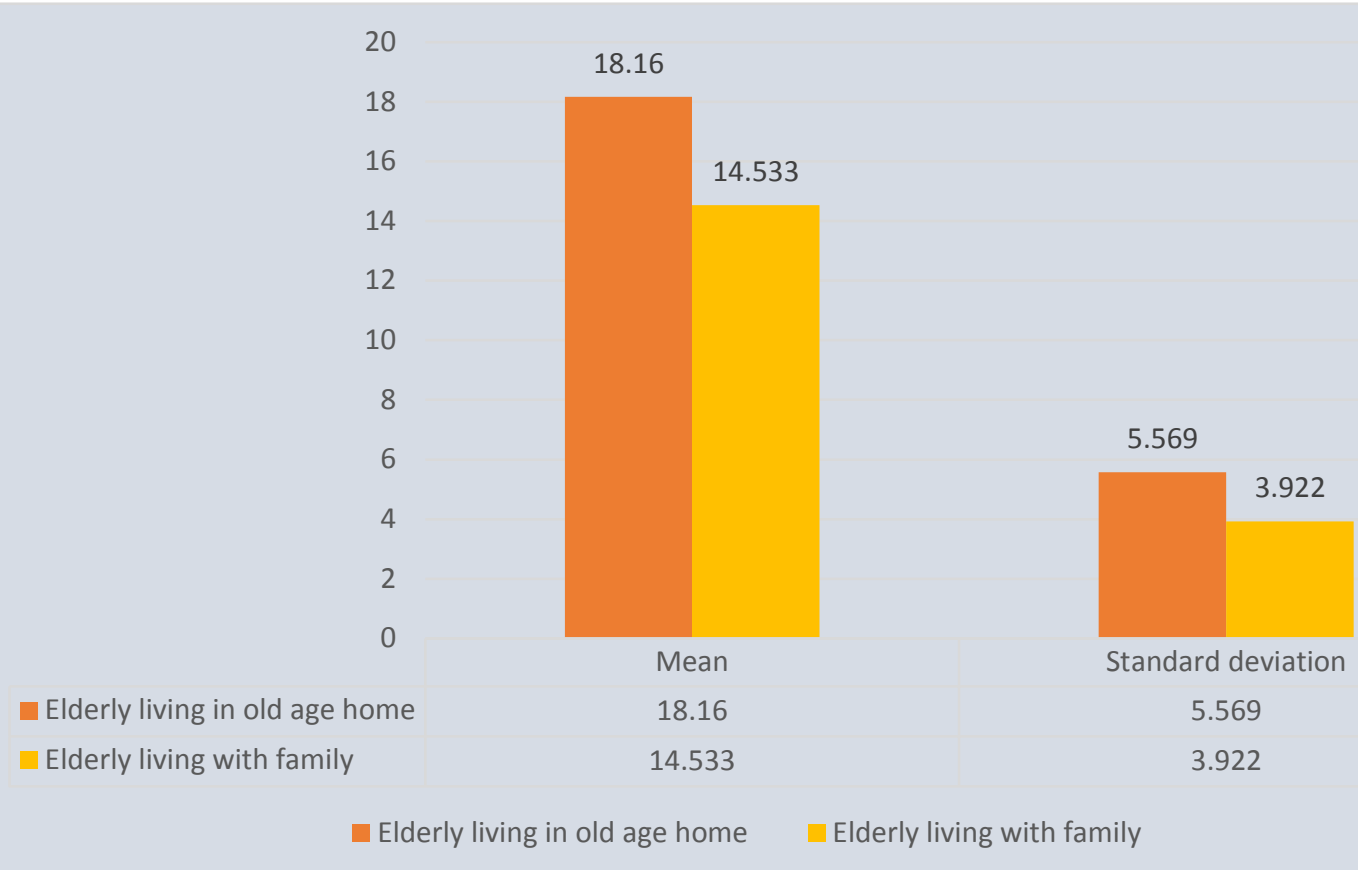

Figure:1- Showing above figure comparison of mean, standard deviation among elderly living in old age homes and living with family members

Table :4- showing the association of selected socio demographic variables with level of Depression among elderly living at old age home and living with family in both groups.

\begin{tabular}{|c|c|c|c|c|c|}
\hline S. No & $\begin{array}{c}\text { Demographic } \\
\text { Variables }\end{array}$ & \multicolumn{2}{|c|}{$\begin{array}{c}\text { Elderly living in old age } \\
\text { home }\end{array}$} & \multicolumn{2}{|c|}{$\begin{array}{c}\text { Elderly living in old age } \\
\text { home }\end{array}$} \\
\cline { 3 - 6 } & & $\begin{array}{c}\text { Chi } \\
\text { Square }\end{array}$ & $\begin{array}{c}\text { 'P' Value } \\
\text { significance }\end{array}$ & $\begin{array}{c}\text { Chi } \\
\text { Square }\end{array}$ & $\begin{array}{c}\text { 'P' Value } \\
\text { significance }\end{array}$ \\
\hline 1 & Age & 5.99 & NS & 0.042 & S \\
\hline 2 & Sex & 15.5 & NS & 12.56 & NS \\
\hline 3 & Marital status & 0.043 & S & 0.038 & S \\
\hline 4 & Educational status & 0.277 & NS & 0.024 & S \\
\hline 5 & Religion & 9.23 & NS & 6.352 & NS \\
\hline 6. & Type of family & 1.21 & NS & 1.286 & NS \\
\hline
\end{tabular}

Note: NS denotes non-significant at $0.05 \%$ level of significance, $S$ denotes significance at $0.05 \%$ level of significance

Above table are showing the association of selected socio demographic variables with level of Depression among elderly living at old age home and living with family in both groups. To test the association between level of depression and age of elderly the null hypothesis can be stated as follows:

\section{IMPLICATIONS}

The findings of the study have implications in various areas of nursing practice, nursing education, nursing administration and nursing research.

\section{Nursing Practice}

Nurses in the community can assess the level of depression among all age groups. Nurses in the health care professionals must plan for implementing awareness programme on depression causing factors and ways for its reduction. Community nurse professional should monitor the mental health of the elderly in the community regularly Nurses by getting knowledge and impact into their clinical practice. 


\section{Nursing Education}

Researcher nurse can teach the student nurses about depression and its preventive ways. Nurse educator must motivate the student nurse to take participate in programs of improving mental health of all age groups. Researcher can organize awareness programs on improving mental health in nursing college. Nurse owes a great responsibility in educating the people regarding depression.

\section{Nursing Research}

More research studies should be conducted in community about level depression. Various intervention-oriented research studies can be done to assess the level of depression and to check the effectiveness of the awareness program on improving mental health. The public and private agencies should also encourage research in this field through materials and funds. The findings of the present study are helpful for the nursing professionals and nursing teachers to conduct further studies to find out the knowledge, attitude and practice of People which are providing education on improving the knowledge regarding depression.

\section{Nursing administration}

Nurse administrator should take interest in motivating the nursing personnel to improve their professional knowledge and skill by attending the workshops, conferences, seminars on depression. Nurse administrator should arrange regular in-service education program to the health care workers for gaining knowledge. The nurse administrators should explore their potentials and encourage innovative ideas in the community People related depression and its effects in health.

\section{RECOMMENDATIONS}

$>$ Similar study can be done with control group.

$>$ Large sample size can be used for the study.

$>$ The study can be replicated in different settings.

$>$ The study can be replicated in different age groups.

CONCLUSION: Level of depression among elderly living in old age home is more having mean value is 18.16 then elderly living with families having mean value is 14.53 . In last we conclude that elderly who are not living with families suffer from more depressed state as compared to those who are living with families.

\section{REFERENCES}

1. Economic and Social Affairs World Population Ageing 2013. New York: United Nations; 2013. [Last accessed on 2016 Jun 04]. United Nations. Available from:

http://www.un.org/en/development/desa/population /publications/pdf/ageing/WorldPopulationAgeing20 13.pdf. [Google Scholar]

2. United Nations, Department of Economic and Social Affairs, Population Division. World Population Ageing 2015,1-3.

3. Saini $S$, Jaswal $S$. A comparative appraisal of Quality of Life (QOL) of aged living with sons and living with daughters. Anthropologist 2009; 11:139-46.

4. Kumar V. Care of the elderly. A training manual for multipurpose health workers and medical officers of primary health care system in India 1996, AIIMS, New Delhi, India, 199.

5. Elderly in India- Profile and Programmes, 2016. Available at: http://www.mospi.gov.in. Accessed on 15 June 2017.

6. George S, Francis PT, Paul N, Leelamoni $K$. Depression among elderly: A comparative study among the elderly living in old age homes and own homes in Ernakulam, Kerala state, India. Int $J$ Emerging Tech Res. 2015;2(4):62-6.

7. Nandi PS, Banerjee G, Mukherjee SP, Nandi $S$, Nandi DN. A study of psychiatric morbidity of the elderly population of a rural community of West Bengal. Indian journal of psychiatry, 1997; 39: 122-129.

8. Alexopolous. Stress, social Engagement and Psychological well-being in Institutional setting. Evidence based on the minimum data set 2.0. Canadian Journal on aging. 19(supple.2) 2005. Pg. no: 50-66.

9. Ingle, Gopal K, Nath A. Geriatric health in India: Concerns and solutions. Indian J Community Med. 2008;33(4):214-8. 